\title{
HASIL TANGKAPAN BEBERAPA JENIS ALAT TANGKAP DI SUNGAI BENGAWAN SOLO
}

\author{
Susilo Adjie dan Agus Djoko Utomo \\ Peneliti pada Balai Riset Perikanan Perairan Umum, Mariana-Palembang \\ Teregistrasi I tanggal: 5 Maret 2010; Diterima setelah perbaikan tanggal: 17 Maret 2010; \\ Disetujui terbit tanggal: 26 Maret 2010
}

\begin{abstract}
ABSTRAK
Penelitian hasil tangkapan beberapa jenis alat tangkap dan kegiatan penangkapan ikan di Bengawan Solo telah dilakukan dari bulan Mei-Desember 2004. Penelitian ini dilakukan dengan metode survei pada empat stasiun pengamatan di Sungai Bengawan Solo yaitu Waduk Gajah Mungkur dan Bendung Colo (bagian hulu), Cemeng (bagian tengah) dan Ngablak (bagian hilir). Hasil tangkapan dan jenis ikan yang tertangkap didapatkan dari nelayan yang dipilih sebagai responden dan dibahas berdasarkan pada musim dan stasiun. Hasil pengamatan menunjukan bahwa ikan tebaran seperti ikan patin jambal (Pangasius hypophthalmus), nila (Oreochromis niloticus), dan tawes (Barbonymus gonionotus) dominan tertangkap di Waduk Gajah Mungkur, Wonogiri. Ikan sapu-sapu (Liposarcus pardalis) ditemukan di daerah Solo-Sragen, sedangkan di bagian hilir antara daerah Bojonegoro sampai Lamongan tertangkap jenis ikan lokal antara lain ikan jambal (Pangasius djambal), lumbet (Cryptopterus spp.), tagih (Mystus nemurus), dan wagal (Pangasius micronema).
\end{abstract}

KATAKUNCl: jenis ikan, hasil tangkapan, Sungai Bengawan Solo

ABSTRACT: Catch of some fishing gear in Solo River. By: Susilo Adjie and Agus Djoko Utomo

A study on determine of some fishing gear activities species in Solo River was conducted from May to December 2004. Observation used in this research was survey method by setting 4 station as long as Solo River, there are Waduk Gajah Mungkur dan Bendung Colo (upstream), Cemeng (middle etream), and Ngablak (down stream). Catching of gear, species was found from responden in every station based on season and station. Research shown that exotic species such as nila (Oreocromis niloticus), jambal (Pangasius hypophthalmus), tawes (Barbodes gonionotus) are commonly found in the upper reaches of the river system. Sapu-sapu (Liposarcus pardalis) is frequently found in the middle river (Cemeng). Native species such as jambal (Pangasius djambal), tagih (Hemibagrus nemurus), wagal (Pangasius micronema), lumbet (Cryptopterus spp.) are normally found in the lower of Bengawan Solo River system (Ngablak).

KEYWORDS: fish species, catch, Bengawan Solo River

\section{PENDAHULUAN}

Bengawan Solo merupakan salah satu sungai terpanjang di Pulau Jawa yang mengalir sepanjang $600 \mathrm{~km}$ melintasi dua propinsi yaitu Jawa Tengah dan Jawa Timur. Aktivitas di bagian hulu Sungai Bengawan Solo adalah pertanian, bagian tengah merupakan daerah padat penduduk dan banyak ditemukan kegiatan industri dan daerah bagian hilir banyak ditemukan usaha tambak ikan. Aktivitas masyarakat yang paling menonjol di daerah Sungai Bengawan Solo di bagian tengah ini dapat berpengaruh langsung terhadap kehidupan organisme yang hidup di air. Menurut Utomo et al. (2004) Sungai Bengawan Solo merupakan contoh tipe perairan umum daratan yang telah banyak mengalami modifikasi atau perubahan terutama untuk keperluan irigasi.
Beberapa tipe modifikasi yang mempengaruhi bentuk keaslian Bengawan Solo antara lain Waduk, Bendungan, Sodetan, Penimbunan, dan lainlain.Beberapa bentuk bendungan yang ada di sepanjang Bengawan Solo antara lain Bendungan Colo (Sukaharjo), Bendungan Karangnongko (Ngawi), Bojonegoro Barrage (Bojonegoro), Babat Barrage (Babat-Tuban), Jabung Dam (Babat), Sembayat Barrage (Lamongan), dan lain lain. Beberapa bentuk Waduk di Bengawan Solo antara lain Waduk Gajah Mungkur (Wonogiri), Waduk Botok (Sragen), dan Waduk Gebyar (Sragen). Bentuk sodetan (floodway) yaitu Sodetan Jabung (Tuban). Kepadatan penduduk di sepanjang sungai sedikit banyak memberi pengaruh terhadap kondisi lingkungan perairan sungai, sekitar 15,2 juta jiwa tinggal di satuan wilayah sungai Bengawan Solo. Pembuangan limbah oleh penduduk ke sungai dapat menimbulkan pencemaran bahan 
organik dan mempengaruhi organisme yang hidup di perairan (Anonimus, 1992;1997; 2003).

Adanya modifikasi badan air dan masuknya berbagai jenis limbah seperti limbah rumah tangga, limbah pabrik tekstil, pabrik kimia, pabrik tapioka, dan limbah biologi memberikan dampak terhadap kegiatan penangkapan ikan terutama alat tangkap dan jenis ikan yang tertangkap. Berdasarkan pada hal tersebut di atas dilakukan penelitian tentang hasil tangkapan beberapa alat tangkap di Sungai Bengawan Solo yang tujuannya dapat memberikan informasi tentang hasil tangkapan nelayan dari beberapa alat tangkap dan jenis-jenis ikan yang tertangkap di Sungai Bengawan Solo.

\section{BAHAN DAN METODE}

\section{Kegiatan Penangkapan}

Penelitian ini dilakukan pada bulan April sampai Desember 2004 di Bengawan Solo Provinsi Jawa Tengah dan Jawa Timur. Survei lapangan dilakukan lima kali yaitu pada bulan Mei, Agustus, September, Oktober, dan Desember 2004 yang mewakili musim kemarau dan penghujan. Parameter yang diamati meliputi jenis ikan, jenis alat tangkap dan hasil tangkapan. Di samping itu juga dilakukan pencatatan data sekunder terutama yang berkaitan dengan keadaan umum daerah.

Stasiun pengamatan dipilih meliputi bagian hulu sampai hilir yaitu bagian hulu meliputi Waduk Gajah Mungkur dan sekitarnya, Bendung Colo (Sukaharja). Bagian tengah meliputi Cemeng (Sragen). Bagian hilir meliputi Ngablak (Lampiran 1). Karena sulitnya mendapatkan data hasil tangkapan secara berkesinambungan maka data hasil tangkapan yang diambil adalah stasiun yang aktivitas penangkapannya cukup tinggi antara lain Waduk Gajah Mungkur dan Bendung Colo yang mewakili bagian hulu, Cemeng (bagian tengah), dan Ngablak yang mewakili bagian hilir Sungai Bengawan Solo.
Hasil tangkapan dikumpulkan dari nelayan yang telah ditetapkan sebagai responden, tiap stasiun pengamatan diambil dua nelayan responden, alat tangkap yang digunakan yaitu strom, jaring, dan jala. Data dianalisis dalam bentuk tabulasi dan secara grafikal dan dibahas untuk melihat gambaran hasil tangkapan di masing-masing stasiun.

Untuk mengetahui gambaran hasil tangkapan ikan selama lima tahun terakhir atau lebih maka dilakukan wawancara dengan nelayan yang mempunyai pengalaman lebih dari lima tahun. Data hasil tangkapan lima tahun terakhir dibuat grafik histogram, sehingga akan kelihatan kecenderungan hasil tangkapan selama lima tahun terakhir.

\section{HASIL DAN BAHASAN}

Kegiatan penangkapan ikan di Sungai Bengawan Solo dilakukan dengan alat tangkap jaring (gillnet), jala (cast net), pancing (hook and line), bubu (pot traps), cerok (scoop net), anco (lift net), dan illegal fishing (kegiatan penangkapan yang dilarang) antara lain strom (electric fishing). Berbeda dengan sungai yang belum banyak mengalami modifikasi dan belum banyak mendapat tekanan ekosistem pada umumnya kegiatan penangkapan lebih kompleks dengan alat yang sederhana sampai pada alat tangkap yang besar. Sebagai contoh di Sungai Musi, Sungai Kapuas, dan Sungai Barito kegiatan penangkapan sudah menjurus ke komersial menggunakan alat tangkap yang besar seperti tuguk (filtering device), hampang (barrier traps), selambau atau kilung (filtering net), ngesar (active seine), ngesek (active barrier), mangumpe (seine with agregating device), dan beje (pond traps), alat tangkap tersebut dapat menangkap dalam jumlah yang besar pada saat musim penangkapan dapat mencapai 100-300 kg/hari (Arifin, 1978; Hoggarth \& Utomo, 1994; Utomo \& Prasetyo 2004).
Gambar 1. Figure 1.

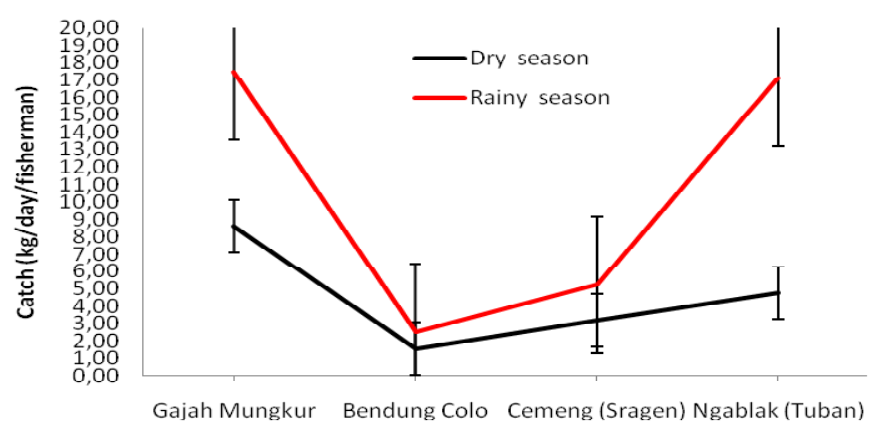

Hasil tangkapan rata-rata ( $\mathrm{kg} /$ hari) per nelayan responden pada keempat stasiun. Average catch rate of fisherman ( $\mathrm{kg} /$ day) in four stations. 
Pada Gambar 1 dapat dilihat bahwa Hasil tangkapan tertinggi ditemukan di Stasiun Waduk Gajah Mungkur (8,6-17,50 kg/hari/nelayan) dan di Stasiun Gablak, Tuban (4,75-17,12 kg/hari/nelayan) baik pada musim kemarau maupun penghujan. Hasil tangkapan terendah ditemukan di Bendung Colo $(1,56-2,5 \mathrm{~kg} /$ hari/nelayan) dan Cemeng (3,2-5,23 kg/hari/nelayan) baik pada musim penghujan maupun kemarau. Hasil tangkapan ikan mulai dari hulu sampai ke bagian hilir lebih tinggi pada musim penghujan dibandingkan dengan musim kemarau. Ini berbeda dengan sungai-sungai lainnya seperti di Sungai Musi
(Rupawan et al., 2008); Sungai Barito (Utomo et al., 2004). Perbedaan ini diduga disebabkan karena morfologi sungai yang telah banyak mengalami modifikasi sehingga mempengaruhi tinggi rendahnya permukaan air sungai.

Hasil tangkapan di Waduk Gajah Mungkur (hulu) didominansi oleh ikan-ikan introduksi seperti ikan nila dan jambal sius (Pangasius hypopthalmus), bagian tengah didominansi ikan sapu-sapu sedangkan hasil tangkapan di Ngablak (hilir) didominansi oleh ikanikan asli yang cukup banyak jenisnya (Tabel 1).

Tabel 1. Jenis ikan yang tertangkap di bagian hulu, tengah, dan hilir selama penelitian Table 1. Fish species that catch in up stream, middle stream, and down stream during reseach

\begin{tabular}{|c|c|c|c|c|}
\hline \multirow[b]{2}{*}{ No. } & \multirow[b]{2}{*}{$\begin{array}{l}\text { Jenis ikan dan nama Indonesia/ } \\
\text { Species and Indonesian name }\end{array}$} & \multicolumn{3}{|c|}{ Lokasi/Location } \\
\hline & & Hulu/Up stream & Tengah/Middle stream & $\begin{array}{l}\text { Hilir/Down } \\
\text { stream }\end{array}$ \\
\hline 1. & Nila (Orechromis nidicus) & $\mathbf{x}$ & & \\
\hline 2. & Jambal sius (Pangasius hypopthalmus) & $\mathrm{x}$ & & $\mathbf{x}$ \\
\hline 3. & Jambal lokal(Pangasius jambal) & $\mathrm{x}$ & & $\mathrm{x}$ \\
\hline 4. & Tawes (Barbonymus gonionotus) & $\mathrm{x}$ & $\mathrm{X}$ & \\
\hline 5. & Sogo (Hemibagrus nemurus) & $\mathrm{x}$ & $\mathrm{X}$ & $\mathbf{x}$ \\
\hline 6. & Lukas (Labiobarbus kptocheilus) & & & $\mathrm{x}$ \\
\hline 7. & Betutu (Oxyeleotris marmorata) & & & $\mathbf{x}$ \\
\hline 8. & Wader (Mystacoleucus marginatus) & & & $\mathrm{x}$ \\
\hline 9. & Kutuk (Channa striata) & & $\mathrm{X}$ & $\mathrm{x}$ \\
\hline 10. & Sapu-sapu (Liposarcus pardalis) & & $\mathrm{x}$ & \\
\hline 11. & Bendol(Barbichthyslaevis) & & & $\mathbf{x}$ \\
\hline 12. & Keting (Bagroides melopterus) & & & $\mathrm{x}$ \\
\hline 13. & Garingan (Mystus singaringan) & & $x$ & $\mathrm{x}$ \\
\hline 14. & Bandeng (Chanos chanos) & & & $\mathbf{x}$ \\
\hline 15. & Bader (Cyclocheilichthys enoplos) & & & $\mathrm{x}$ \\
\hline 16. & Wader pari(Rasbora lateristriata) & & & $\mathbf{x}$ \\
\hline 17. & Wagal (Pangasius polyuranodon) & & & $\mathrm{x}$ \\
\hline 18. & Conggah (Macrobracium rosenbergi) & & & $\mathrm{x}$ \\
\hline 19. & Arengan (Labeo chrysophekeadion) & & & $\mathrm{x}$ \\
\hline 20. & Sili (Macrognathus aculeatus) & & & $\mathbf{x}$ \\
\hline 21. & Lumbet (Kryptopterus spp.) & & & $\mathbf{x}$ \\
\hline 22. & Lemper (Notopterus notopterus) & & & $\mathrm{x}$ \\
\hline
\end{tabular}

Pada Tabel 1 dilihat bahwa jenis ikan yang tertangkap selama penelitian terdiri atas 22 jenis dan empat jenis di antaranya merupakan ikan introduksi, keanekaragaman jenis ikan di Sungai Bengawan Solo lebih kecil dibandingkan dengan sungai yang belum banyak mengalami modifikasi dan belum banyak mendapatkan tekanan ekosistem. Ini lebih kecil dibandingkan dengan keragaman jenis ikan di Sungai Musi terdapat lebih dari 130 jenis ikan (Utomo et al., 1993; Samuel et al., 2001), Sungai Kapuas lebih dari 200 jenis ikan (Dudley, 1996), Sungai Barito lebih dari 107 jenis ikan (Prasetyo et al., 2003).

\begin{abstract}
Alat Tangkap dan Hasil Tangkapan

\section{Bagian hulu}

Alat tangkap utama di Waduk Gajah Mungkur yaitu jaring gillnet ukuran mata 2-4 inci dan 5-7 inci. Hasil tangkapan jaring ukuran mata 2-4 inci didominansi oleh ikan tawes dan nila, sedangkan ukuran mata 5-7 inci didominansi oleh ikan jambal siam yang puncak musimnya pada musim penghujan (Gambar 2). Berdasarkan pada jenis alat tangkap, ikan jambal merupakan jenis yang paling banyak tertangkap dengan jaring ukuran mata jaring 5-7 inci diikuti oleh ikan nila yang tertangkap dengan alat tangkap jaring ukuran mata 2-4 inci $60 \%$ dan ikan tawes $40 \%$.
\end{abstract}


Kegiatan penangkapan di Waduk Gajah Mungkur didominansi oleh alat tangkap jaring ( gillnet) berukuran mata jaring 3-7 inci. Jaring ukuran 3-4 inci digunakan untuk menangkap ikan ukuran kecil sampai sedang seperti ikan nila, tawes, nilem, lukas, dan lain-lain. Sedangkan jaring ukuran 5-7 inci digunakan untuk menangkap ikan berukuran sedang sampai besar seperti ikan sogo, jambal, dan betutu.

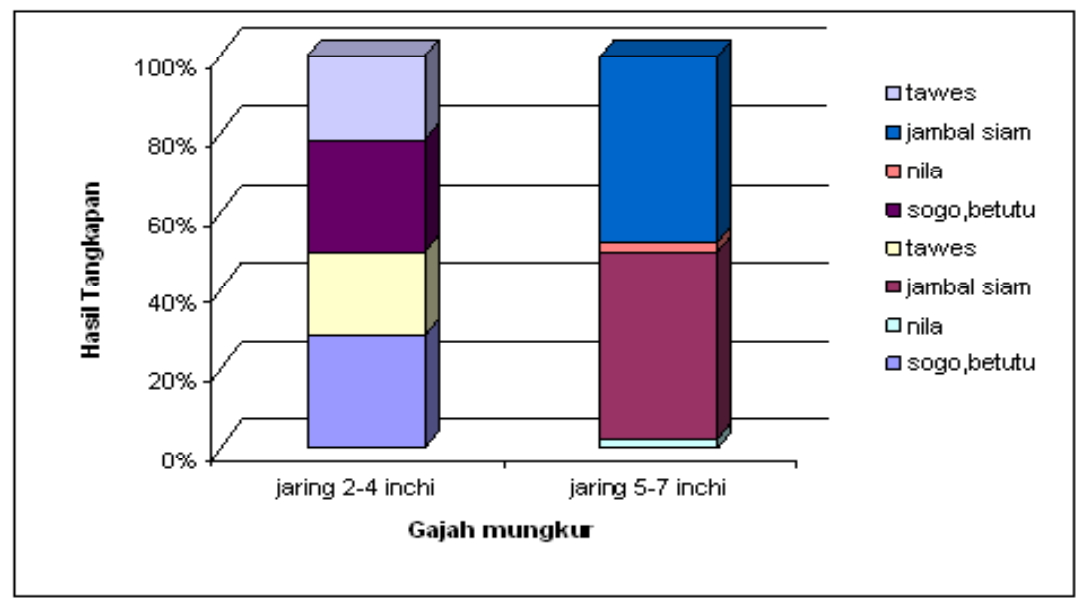

Gambar 2. Hasil tangkapan jaring insang dengan ukuran mata jaring 2-4 inci dan 5-7 inci di Waduk Gajah Mungkur.

Figure 2. Catching rate of gillnet with mesh size of 2-4 inchies and 5-7 inchies in Gajah Mungkur Reservoir.

Spesies ikan jambal yang termasuk familinya pangasiidae di Bengawan Solo Provinsi Jawa Tengah selama penelitian ditemukan satu jenis ikan jambal yaitu ikan jambal sius. Ikan jambal sius ini mula-mula merupakan ikan tebaran di waduk Gajah Mungkur, Wonogiri. Ikan ini kian lama dapat berkembang dengan baik selama lima tahun terakhir (Gambar 3 ), hal ini disebabkan karena di waduk Gajah Mungkur banyak tersedia pakan alami yang sesuai yaitu plankton dan detritus (Purnomo et al., 2003). Di sepanjang Sungai Bengawan Solo diketemukan tiga jenis ikan yang termasuk famili Pangasiidae yaitu jambal siam, jambal lokal (Pangasius jambal), dan wagal atau jendil (Pangasius mikronema) (Utomo et al., 2004).

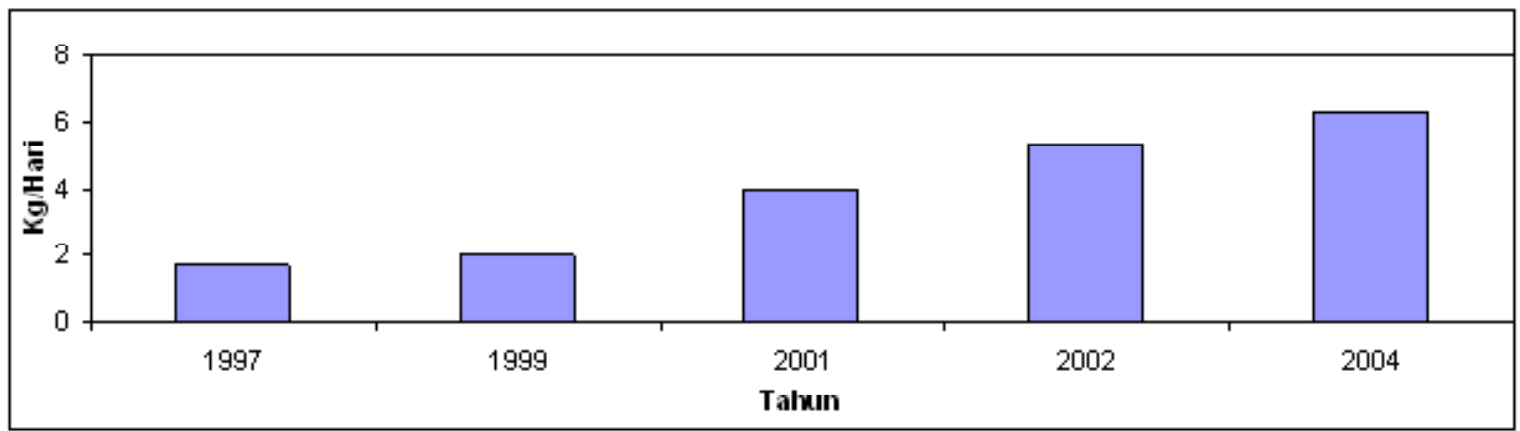

Gambar 3. Hasil tangkapan ikan jambal sius dengan jaring ukuran 4 inci di Waduk Gajah Mungkur, Wonogiri.

Figure 3. Catch rate of ikan jambal sius with jarring of mesh size 4 inchies in Gajah Mungkur Reservoir, Wonogiri. 
Hasil tangkapan ikan jambal sius saat musim kemarau banyak terdapat di daerah teluk dari Waduk Gajah Mungkur, karena di daerah teluk banyak terdapat kayu duri (Mimosa nigra) yang merupakan habitat daerah naungan bagi ikan jambal sius terutama yang berukuran kecil $(20-30 \mathrm{~cm})$. Habitat tempat mencari makan bagi ikan jambal sius yaitu di dekat pintu bendungan (outlet) waduk dan di karamba jaring apung, hal ini terjadi karena di dekat pintu bendungan banyak terdapat endapan lumpur yang banyak mengandung detritus dan di karamba jaring apung, ikan jambal sius memanfaatkan sisasisa pakan ikan peliharaan.
Gambar 4 menunjukan bahwa hasil tangkapan ikan nila selama lima tahun terakhir di Waduk Gajah Mungkur menunjukan peningkatan dan merupakan ikan dominan ke dua setelah ikan patin sius. Keberadaan ikan nila di waduk Gajah Mungkur disebabkan adanya penebaran dan adanya ikan yang terlepas dari karamba. Ikan ini mulai berkembang sejak dilakukan penebaran oleh Pemerintah Daerah Provinsi Jawa Tengah mulai tahun 1981-2003 telah menebar benih ikan nila dan tawes 1.911 .000 ekor, kelompok nelayan setempat telah menebar 593.000 ekor benih ikan tawes, nila, dan jambal sius, dan pada tahun 2002 telah ditebar ikan patin sejumlah 30.000 ekor oleh Pusat Riset Perikanan Tangkap, Jakarta untuk kepentingan penelitian (Anonimus, 2003).

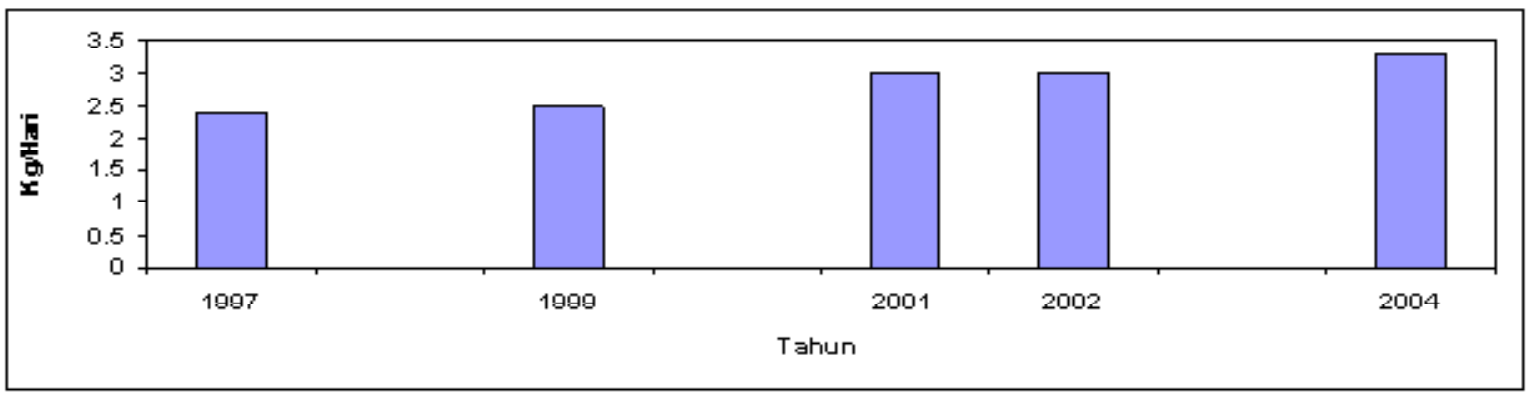

Gambar 4. Hasil tangkapan ikan nila dengan jaring gillnet ukuran mata 3 inci di Waduk Gajah Mungkur, Wonogiri.

Figure 4. Catch rate of Oreochromis niloticus caught gillnet with mesh size 3 inchies in Gajah Mungkur Reservoir, Wonogiri.

Di samping ikan tebaran, banyak ditemukan ikan asli antara lain ikan sogo (Hemibagrus nemurus). Dari Gambar 5 dapat dilihat adanya peningkatan hasil tangkapan selama lima tahun terakhir. Meningkatnya jumlah ikan ini dari tahun ke tahun mungkin disebabkan tingkat tropik makanan ikan sogo berbeda dengan ikan ke dua ikan dominan (nila dan jambal sius) di waduk Gajah Mungkur. Berdasarkan Utomo et al. (1993) Ikan sogo merupakan ikan pemakan segala lebih cenderung sebagai ikan karnivor. Di duga ikan ini memangsa larva dan juvenil ikan nila dan tawes yang banyak terdapat di waduk Gajah Mungkur. Sebaliknya ikan tawes (Barbonymus gonionotus) mengalami penurunan dari tahun ke tahun (Gambar 6), penurunan ini diduga karena adanya persaingan makanan dengan ikan introduksi dan adanya faktor predasi.

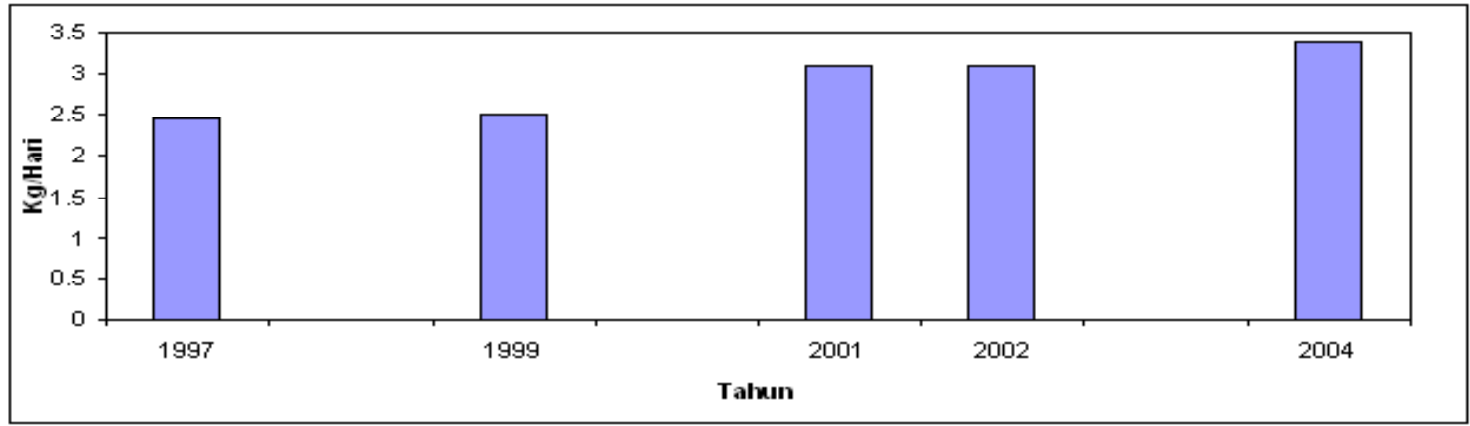

Gambar 5.

Hasil tangkapan ikan sogo dengan jaring 4 inci di Waduk Gajah Mungkur, Wonogiri. Figure 5. 


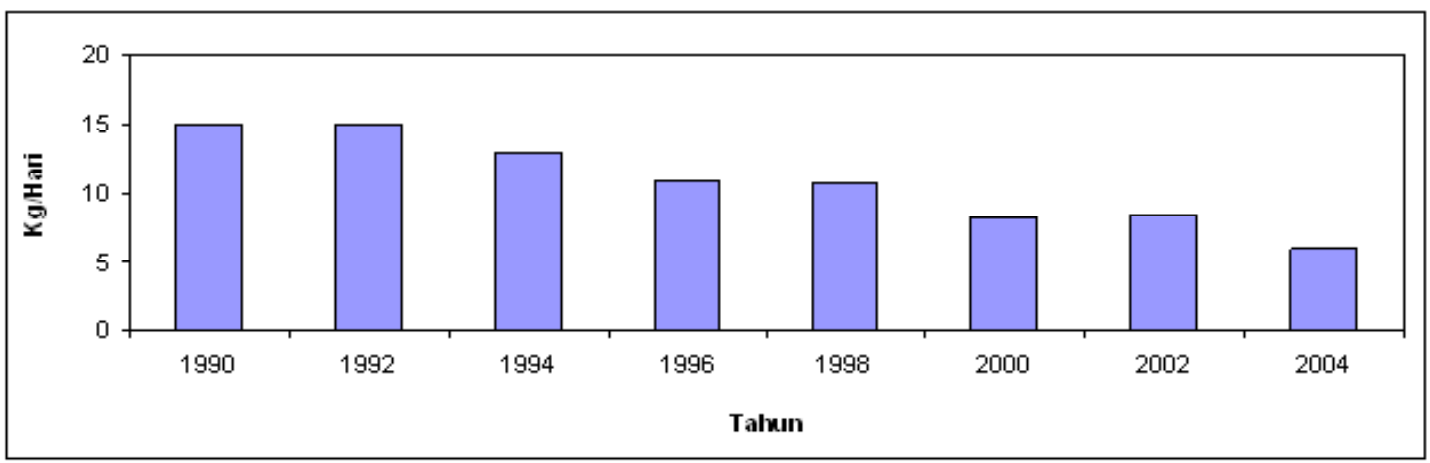

Gambar 6.

Hasil tangkapan ikan tawes dengan alat tangkap jala di Bendung Colo, Sukaharjo.

Figure 6. Catch rate of ikan tawes with cast net in Bendung Colo, Sukoharjo.

Kegiatan penangkapan di stasiun pengamatan Bendung Colo (Sukaharja) tidak dilakukan sepanjang tahun hanya saat air besar datang dari hulu sungai ada kegiatan penangkapan, alat yang digunakan dengan alat jala dan jaring gillnet, sifat kegiatan penangkapan hanya sambilan, dalam satu tahun lamanya penangkapan hanya 2-4 bulan. Pada bulan Mei 2004 hasil tangkapan rata-rata per orang 1,56 kg terdiri atas ikan tawes 76,8\%, sogo 18,2\%, dan lainlain (ikan nila 2,3\% dan beloso 2,7\%), pada saat musim penghujan hasil tangkapannya mengalami kenaikan yaitu $1,56 \mathrm{~kg} /$ hari/orang menjadi $2,5 \mathrm{~kg} / \mathrm{hari} /$ orang.
Kegiatan penangkapan di stasiun pengamatan Bendung Colo (Sukaharja) tidak dilakukan sepanjang tahun hanya saat air besar datang dari hulu sungai ada kegiatan penangkapan, alat yang digunakan dengan alat jala dan jaring gillnet, sifat kegiatan penangkapan hanya sambilan, dalam satu tahun lamanya penangkapan hanya 2-4 bulan. Pada bulan Mei 2004 hasil tangkapan rata-rata per orang 1,56 kg terdiri atas ikan tawes $76,8 \%$, sogo $18,2 \%$, dan lainlain (ikan nila 2,3\% dan beloso 2,7\%), pada saat musim penghujan hasil tangkapannya mengalami kenaikan yaitu 1,56 kg/hari/orang menjadi $2,5 \mathrm{~kg} / \mathrm{hari} /$ orang.

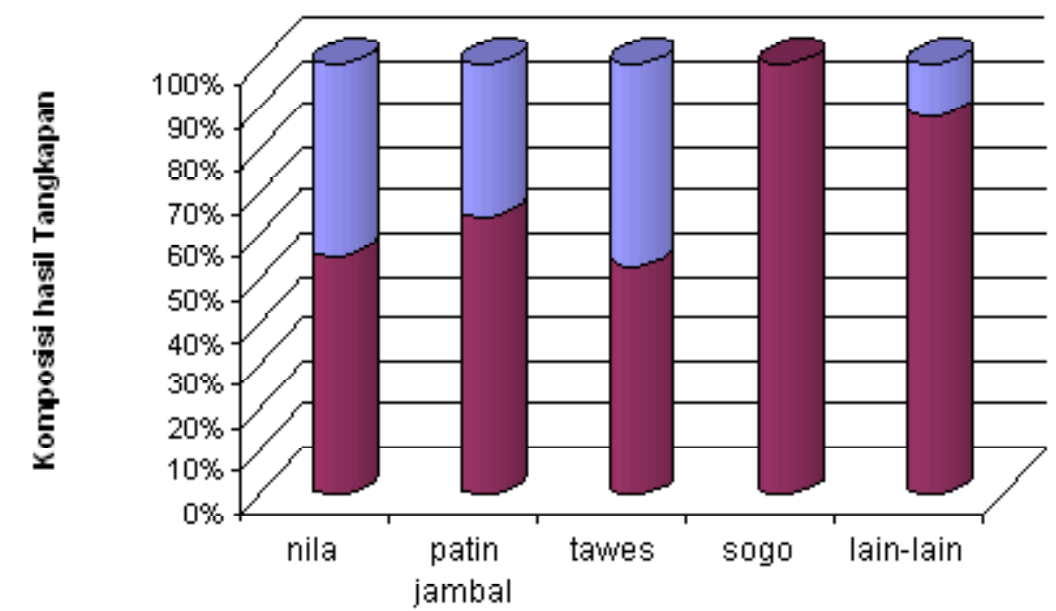

Gajah Mungkur

Gambar 7. Hasil tangkapan ikan di waduk Gajah Mungkur pada musim kemarau dan penghujan. Figure 7. Catch composition of fish in Gajah Mungkur reservoirs in dry and rainy season. 
Musim penangkapan di Waduk Gajah Mungkur sepanjang tahun dengan puncak musim dimulai awal musim penghujan sampai kemarau. Berdasarkan pada hasil pengamatan dari responden di Waduk Gajah Mungkur terlihat bahwa hasil tangkapan pada musim kemarau dengan alat tangkap gillnet didominansi oleh ikan nila, jambal, tawes dan lainlain (Gambar 7). Hasil tangkapan saat kemarau per orang per hari rata-rata $8,6 \mathrm{~kg}$ dengan komposisi ikan nila $40,30 \%$, jambal siam $28,8 \%$, tawes $24,75 \%$, sogo $15 \%$, dan lain-lain 1\% (ikan betutu (Oxyleotris marmorata) dan lukas (Labiobarbus leptocheilus)). Hasil tangkapan di Waduk Gajah Mungkur pada saat musim penghujan mengalami kenaikan menjadi 17,50 $\mathrm{kg} / \mathrm{hari} /$ orang (Gambar 1). Hasil tangkapan ikan patin jambal mengalami kenaikan yang berarti yaitu dari $28,8 \%$ saat kemarau menjadi $37,7 \%$ saat musim penghujan. Akhir-akhir ini hasil tangkapan ikan nila dan patin jambal mengalami kenaikan menempati urutan pertama dan kedua, bila dibandingkan penelitian Purnomo (2003) yang mengatakan bahwa pada tahun 1999 hasil tangkapan ikan patin (patin jambal) menempati urutan ketujuh dan ikan nila urutan kesembilan.

Nelayan di Gajah Mungkur sudah terorganisir, ada kelompok nelayan. Penjualan ikan dilakukan di tempat pendaratan ikan, jumlah tempat pendaratan ikan ada lima buah tiap hari rata-rata dapat mendaratkan ikan 300-1.000 kg, produksi perikanan tangkap $107 \mathrm{~kg} / \mathrm{ha} /$ tahun (luas waduk $8.800 \mathrm{ha}$ ). Jumlah kelompok nelayan dan petani ikan ada 18 kelompok dengan jumlah anggota 584 orang (Anonimus, 2003). Di samping nelayan, tiap hari banyak pemancing di waduk atau di sungai yang ke luar dari waduk, rata-rata jumlah pemancing ada 2030 orang dengan hasil rata-rata $0,5-2 \mathrm{~kg}$.

\section{Bagian tengah}

Alat tangkap utama di daerah Cemeng-Sragen yaitu jala dan jaring gillnet, jenis ikan sapu-sapu mendominansi hasil tangkapan. Pada Gambar 8 dilihat bahwa hasil tangkapan jaring gillnet 100\% ikan tawes. Kegiatan penangkapan di stasiun pengamatan Desa Cemeng (Sragen) dilakukan sepanjang tahun dengan alat tangkap jala, jaring, dan sekali-kali dengan serok apabila sedang ada ikan mabuk karena pencemaran air. Saat hujan datang sering ada ikan mabuk yang datangnya dari arah hulu melewati daerah Sragen yang perairannya sudah banyak terjadi pencemaran, ikan tersebut antara lain ikan tawes. Untuk menangkap ikan yang sedang mabuk tersebut sering digunakan alat tangkap jala dan serok, dengan demikian saat terjadi ikan mabuk alat jala banyak menangkap ikan tawes (Gambar 9).

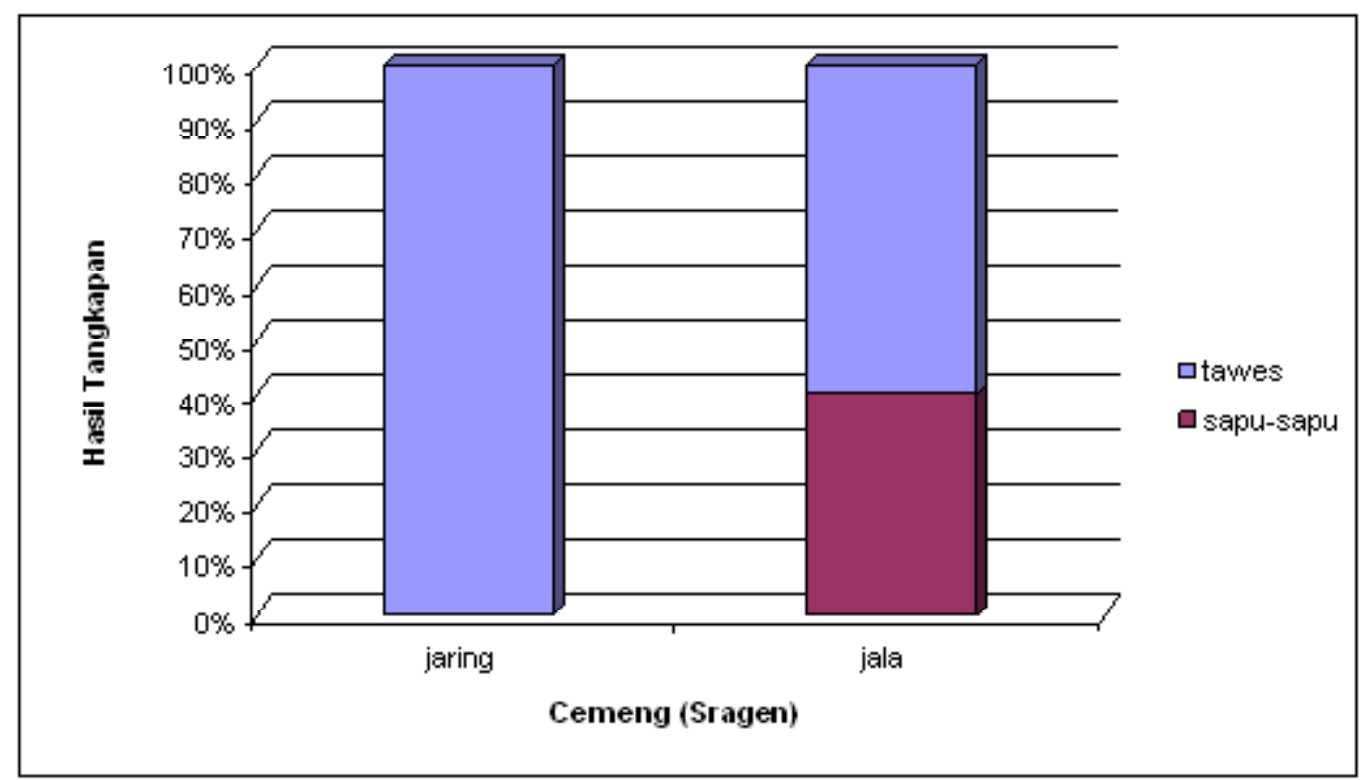

Gambar 8. Hasil tangkapan berdasarkan pada alat tangkap jaring dan jala di stasiun Cemeng (Sragen). Figure 8. Catches by fishing gears gillnet and castnet in the Station Cemeng (Sragen). 


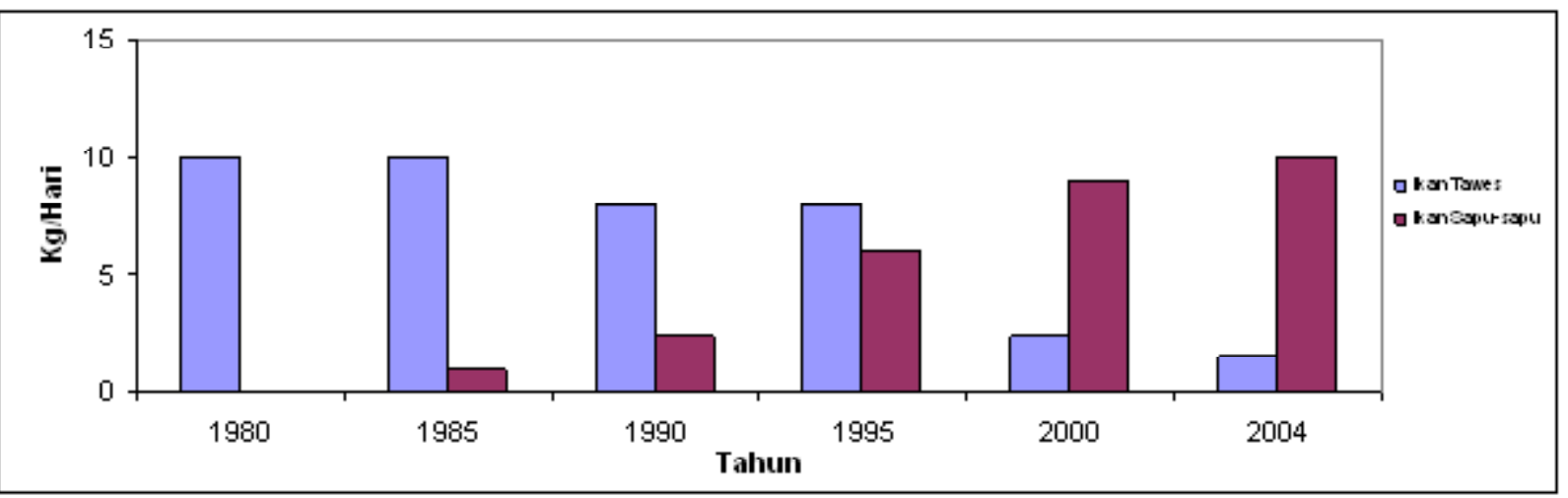

Gambar 9. Jenis hasil tangkapan dengan alat tangkap jala di Desa Cemeng-Sragen selama lima tahun terakhir.

Figure 9. Catch of fish caught by cash net in Cemeng-Sragen last five years.

Gambar 9 memperlihatkan adanya penurunan hasil tangkapan ikan tawes di mana kurun waktu tahun 1980-1985 ikan tawes mendominansi hasil tangkapan, tahun 1990-1996 hasil tangkapan sudah menurun dan sejak tahun 2000 hasil tangkapan menjadi di bawah
$5 \mathrm{~kg} / \mathrm{hari}$. Sebaliknya hasil tangkapan ikan sapu-sapu meningkat sejak tahun 1995 dan 2004 ikan sapu-sapu mendominansi hasil tangkapan. Pada Gambar 10 dapat dilihat dominansi ikan sapu-sapu.

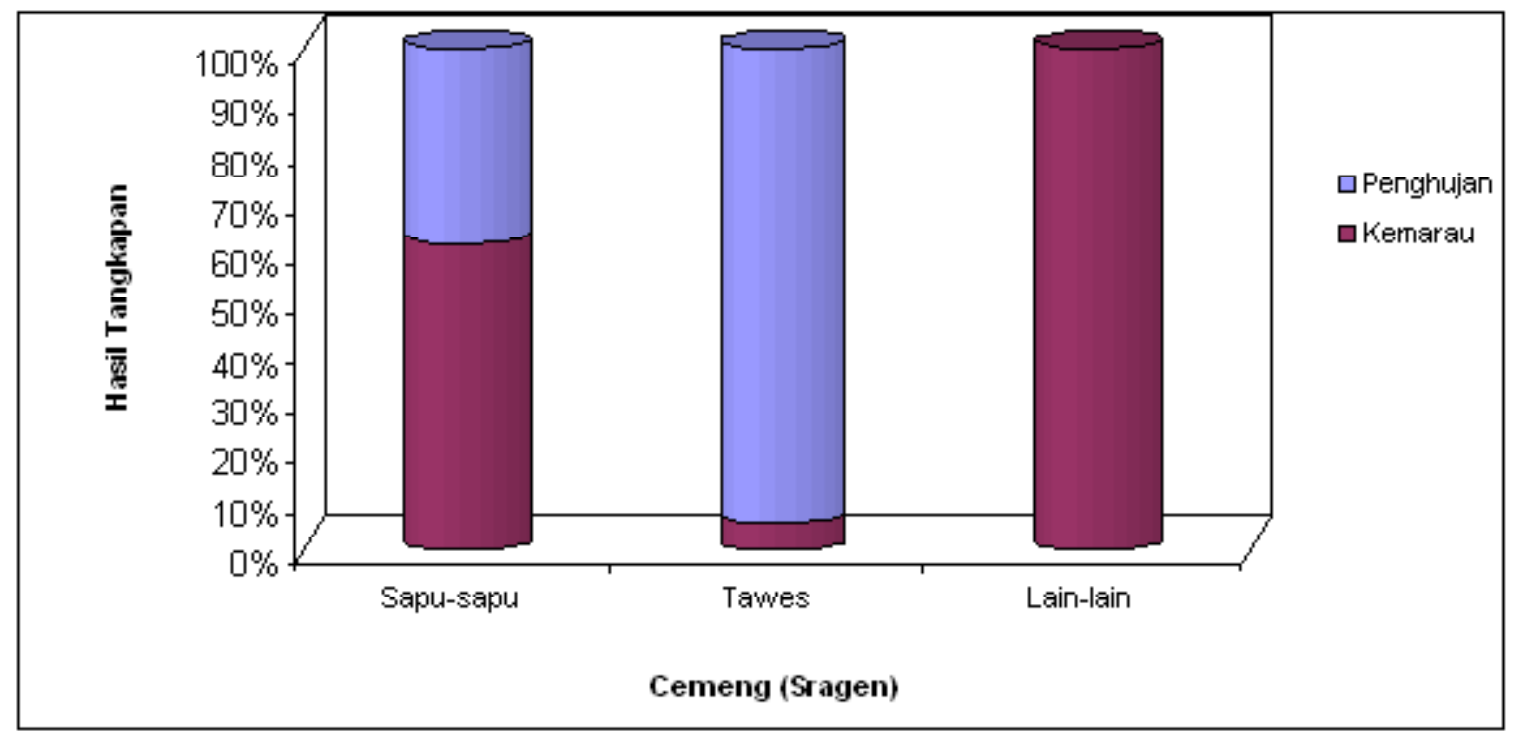

Gambar 10. Komposisi hasil tangkapan ikan pada musim kemarau dan penghujan di Stasiun Cemeng.

Figure 10. Catch composition in dry season and rainy season in Cemeng Station.

Pada saat musim kemarau hasil tangkapan ratarata per orang $3,2 \mathrm{~kg} / \mathrm{hari}$ dengan komposisi ikan sapusapu $90,4 \%$, tawes $5,1 \%$, dan lain-lain (ikan garingan (Mystus singaringan) dan wader (Mystacoleucus marginatus) $2,5 \%$. Pada saat musim penghujan hasil tangkapan mengalami kenaikan menjadi $5,23 \mathrm{~kg} / \mathrm{hari} /$ orang saat musim penghujan, tangkapan ikan tawes mengalami kenaikan yang cukup berarti yaitu dari $5,1 \%$ saat kemarau menjadi $51,31 \%$ saat musim penghujan. Ikan sapu-sapu merupakan jenis ikan yang tahan terhadap pencemaran, namun harganya tidak ekonomis dan sulit dipasarkan. Pada Sungai Bengawan Solo di daerah Jurug (Solo) yang termasuk bagian tengah sering tertangkap ikan kutuk, lele (Clarias spp.), dan mujair, ikan mujair berasal dari ikan terlepas dari budi daya ikan di kolam. Pada saat tertentu ditemukan banyak ikan mabuk karena adanya pencemaran perairan, jenis ikan tersebut antara lain ikan tawes, garingan, dan tagih. 
Ikan lokal tiap tahun cenderung mengalami penurunan hal ini disebabkan karena habitat aslinya telah banyak mengalami perubahan dan tidak pernah dilakukan penebaran kembali. Ikan sapu-sapu merupakan ikan yang tahan terhadap pencemaran, pemakan bahan organik sehingga pada stasiun pengamatan di Desa Cemeng yang kualitas airnya buruk dan terindikasi sudah tercemar, ikan tersebut sangat mendominansi.

\section{Bagian hilir}

Pada musim penghujan hasil tangkapan lebih tinggi dibandingkan pada musim kemarau dan jenis ikan lebih bervariasi yaitu dari 4,75 kg/hari/orang pada saat kemarau menjadi $17,12 \mathrm{~kg} /$ hari/orang pada musim penghujan (Gambar 1). Komposisi hasil tangkapan berkisar antara 1,57-23,4\% sedangkan pada musim kemarau komposisi hasil tangkapan tertinggi yaitu ikan wagal (47\%) sedangkan jenis ikan lainnya berkisar antara 1,43-20,1\% (Gambar 11). Alat tangkap utama di daerah Ngablak-Tuban yaitu jaring dan strom, jenis ikan yang tertangkap lebih beragam daripada di daerah tengah dan hulu terutama ikan lokal. Komposisi hasil tangkapan dengan jaring dan strom dapat diihat pada Tabel 2.

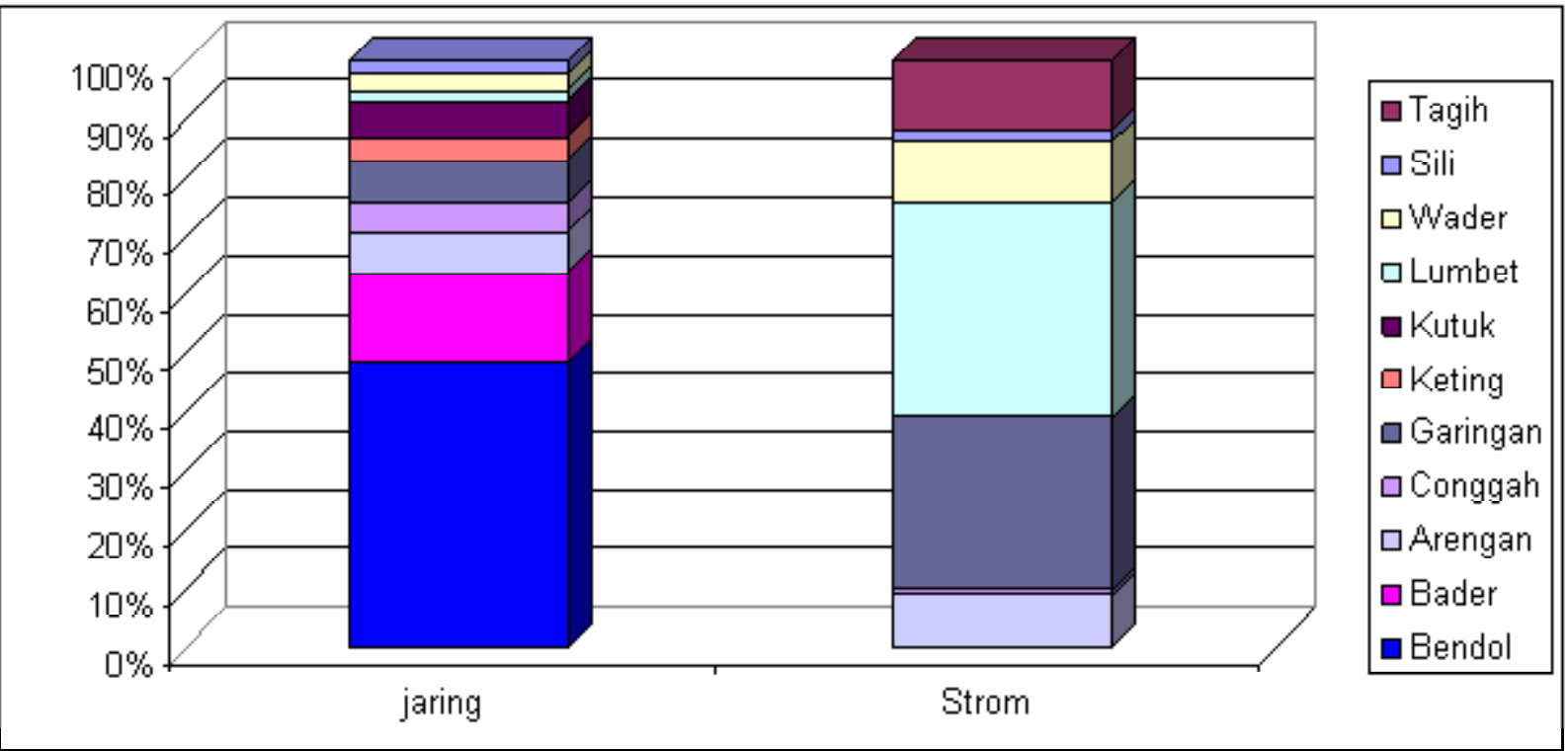

Gambar 11.

Komposisi hasil tangkapan (\%) ikan di Ngablak selama musim penghujan dan kemarau. Figure 11. Catch composition (\%) in Ngablak stasiun during rainy season and dry season.

Pada Gambar 11 dapat dilihat bahwa keanekaragaman jenis ikan yang tertangkap lebih tinggi pada musim penghujan dibandingkan pada musim kemarau. Keanekaragaman jenis ikan yang tertangkap 12 jenis pada musim kemarau dan delapan jenis pada musim kemarau. Tabel 2 menunjukan ikan bendol (Barbichthys laevis) merupakan jenis ikan yang dominan tertangkap dengan jaring disusul dengan ikan bader (Cyclocheilichthys enoplos) dan arengan (Labeo chrysophekeadion), kehadiran ikanikan ini telah menunjukan bahwa kondisi kualitas lingkungan perairan Sungai Bengawan Solo bagian hilir cukup baik.
Penangkapan ikan ukuran besar seperti ikan wagal dan sogo dilakukan di lubuk sungai terutama saat kemarau, karena lubuk terutama yang terdapat gua merupakan tempat perlindungan dan persembunyian bagi ikan berukuran besar. Hasil tangkapan ikan wagal selama lima tahun terakhir mengalami penurunan yaitu dari $3 \mathrm{~kg} / \mathrm{nelayan} / \mathrm{hari}$ pada tahun 1997 mengalami penurunan sampai 1,6 kg/nelayan/hari (Gambar 12). 
Tabel 2. Komposisi hasil tangkapan ikan dengan alat tangkap jaring dan strom di Stasiun Ngablak Table 2. Catch composition caught by gillnet and electric fishing in Ngablak Station

\begin{tabular}{lcc}
\hline \multicolumn{1}{c}{ Jenis ikan/Fishes species } & \multicolumn{2}{c}{ Hasil tangkapan/Catch $(\%)$} \\
\cline { 2 - 3 } & Jaring/Net (\%) & Strom/Stroom (\%) \\
\hline Bendol (Barbichthys laevis) & 53,76 & - \\
Bader (Cyclocheilichthys enoplos) & 14,66 & - \\
Arengan (Labeo chrysophekeadion) & 6,39 & 2,12 \\
Conggah (Macrobracium rosenbergii) & 5,64 & 32,51 \\
Garingan (Mystus singaringan) & 6,77 & 40,28 \\
Keting (Bagroides melopterus) & 4,13 & - \\
Kutuk (Channa striata) & 3,38 & - \\
Lumbet (Kryptopterus spp.) & 2,07 & 10,60 \\
Wader (Mystacoleucus marginatus) & 1,88 & 13,01 \\
Tagih (Mystus nemurus) & 0,50 & 1,41 \\
Sili (Macrognathus aculeatus) & 0,81 & \\
\hline
\end{tabular}

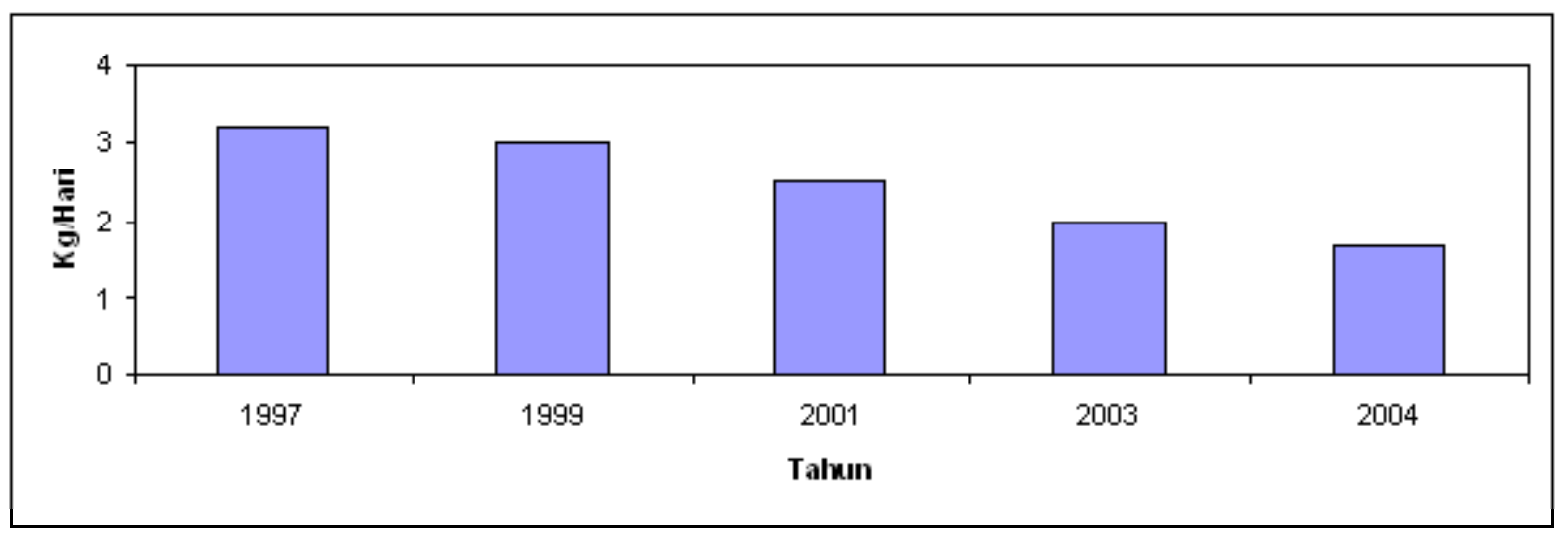

Gambar 12. Hasil tangkapan ikan wagal dengan Jaring 3,5 inci di Desa Ngablak, Tuban. Figure 12 Pangasius micronema catch with gillnet of mesh size 3 inchies.

\section{KESIMPULAN}

1. Jenis ikan eksotik seperti ikan nila dan jambal sius telah mendominansi hasil tangkapan di Waduk Gajah Mungkur Wonogiri (daerah hulu).

2. Daerah tengah (Cemeng) yang merupakan perairan yang tercemar, hasil tangkapan didominansi oleh ikan sapu-sapu.

3. Hasil tangkapan di perairan di Ngablak-Tuban, Bojonegoro (daerah hilir) ditemukan jenis ikan lokal yang bernilai ekonomis seperti ikan jambal lokal, tagih, lumbet, lemper, dan wagal.

4. Kegiatan penangkapan ikan yang menonjol hanya di perairan Waduk Gajah Mungkur.
5. Hasil tangkapan tertinggi ditemukan di stasiun Waduk Gajah Mungkur (8,6-17,50 kg) dan di Stasiun Ngablak, Tuban $(4,75-17,12 \mathrm{~kg})$, hasil tangkapan terendah ditemukan di Stasiun Cemeng $(3,2-5,23)$ baik pada musim penghujan maupun kemarau.

\section{PERSANTUNAN}

Tulisan ini merupakan kontribusi dari kegiatan hasil riset kajian keragaman jenis ikan dan kegiatan pemanfaatan sumber daya perikanan perairan umum Bengawan Solo, T. A. 2004, di Balai Riset Perikanan Perairan Umum-Mariana, Palembang. 


\section{DAFTAR PUSTAKA}

Anonimus. 1992. Rencana Pengelolaan Lingkungan Waduk Wonogiri. Departemen Pekerjaan Umum. Pusat Penelitian Kependudukan dan Lingkungan Hidup. Universitas Diponegoro. Semarang.

Anonimus. 1997. Rencana Pengelolaan Lingkungan, Rencana Pemantauan Lingkungan pada AMDAL Perbaikan dan Pengaturan Sungai Bengawan Solo bagian Hilir. Direktur Jenderal Pengairan. Departemen Pekerjaan Umum. Proyek Induk Pengembangan Wilayah Bengawan Solo.

Anonimus. 2003. Pengelolaan Usaha Perikanan di Waduk Gajah Mungkur Kabupaten Wonogiri. Dinas Kehewanan, Perikanan, dan Kelautan Kabupaten Wonogiri.

Arifin, Z. 1978. Beberapa aspek tentang penangkapan ikan di perairan lubuk lampam Sumatera Selatan. Disampaikan dalam Simposium Modernisasi Perikanan Rakyat di Jakarta. Tanggal 27-30 Juni 1978. LPPD Cabang Palembang. 25 pp.

Dudley, R. G 1996. The Fishery of the Danau Sentarum Wildlife Reserve West Kalimantan Indonesia. AWB. Bogor. 1-10.

Hoggarth, D. D. \& A. D. Utomo. 1994. The fisheries ecology of lubuk lampam river floodplain in South Sumatera, Indonesia. International Journal Fisheries Research. Elsevier. London. 20: 191-213.

Prasetyo, D., Asyari, \& Rupawan. 2003. Keragaman jenis ikan di Sungai Barito. Laporan Teknis Balai Riset Perikanan Perairan Umum. Palembang.
Purnomo, K., E. S. Kartamihardja, \& S. Koeshendradjana. 2003. Pertumbuhan, mortalitas, dan kebiasaan makan ikan patin siam (Pangasius hypopthalmus) introduksi di Waduk Gajah Mungkur. Jurnal Penelitian Perikanan Indonesia Edisi Sumber Daya dan Penangkapan. Pusat Riset Perikanan Tangkap. Badan Riset Kelautan dan Perikanan. Jakarta. 9 (3): 13-21.

Rupawan, A. K. Gaffar, \& K. Fattah. 2008. Spesifikasi, Cara Operasi, dan Hasil Tangkapan Alat Tangkap Blad (Beach Barrier Trap) di Perairan Estuari yang Bermuara di Selat Bangka, Sumatera Selatan.

Samuel, S. Adjie, \& Subagja. 2001. Inventarisasi dan distribusi biota serta karakteristik habitat Sungai Musi. Laporan Teknis Balai Riset Perikanan Perairan Umum. Palembang.

Utomo, A. D., S. Adjie, N. Muflikhah, \& A. Wibowo. 2004. Distribusi jenis ikan dan kualitas perairan di Bengawan Solo. Jurnal Penelitian Perikanan Indonesia Edisi Sumber Daya dan Penangkapan. Pusat Riset Perikanan Tangkap. Badan Riset Kelautan dan Perikanan. Jakarta. 12 (2): 89-100.

Utomo, A. D., Z. Nasution, \& S. Adjie. 1993. Kondisi ekologi dan potensi sumber daya perikanan Sungai Musi. Prosiding Temu Karya IImiah Perikanan Perairan Umum. Pengkajian Potensi dan Prospek Pengembangan Perairan Umum Sumatera Selatan. Pusat Penelitian dan Pengambangan Perikanan. Jakarta.

Utomo, A. D. \& D. Prasetyo. 2004. Evaluasi kegiatan penangkapan ikan di Sungai Barito Kalimantan Tengah dan Selatan. Laporan Teknis Balai Riset Perikanan Perairan Umum. Palembang. 
BAWAL: Vol.3 No.1-April 2010: 33-44

Lampiran 1. Peta lokasi penelitian

Appendix 1. Map location of this research

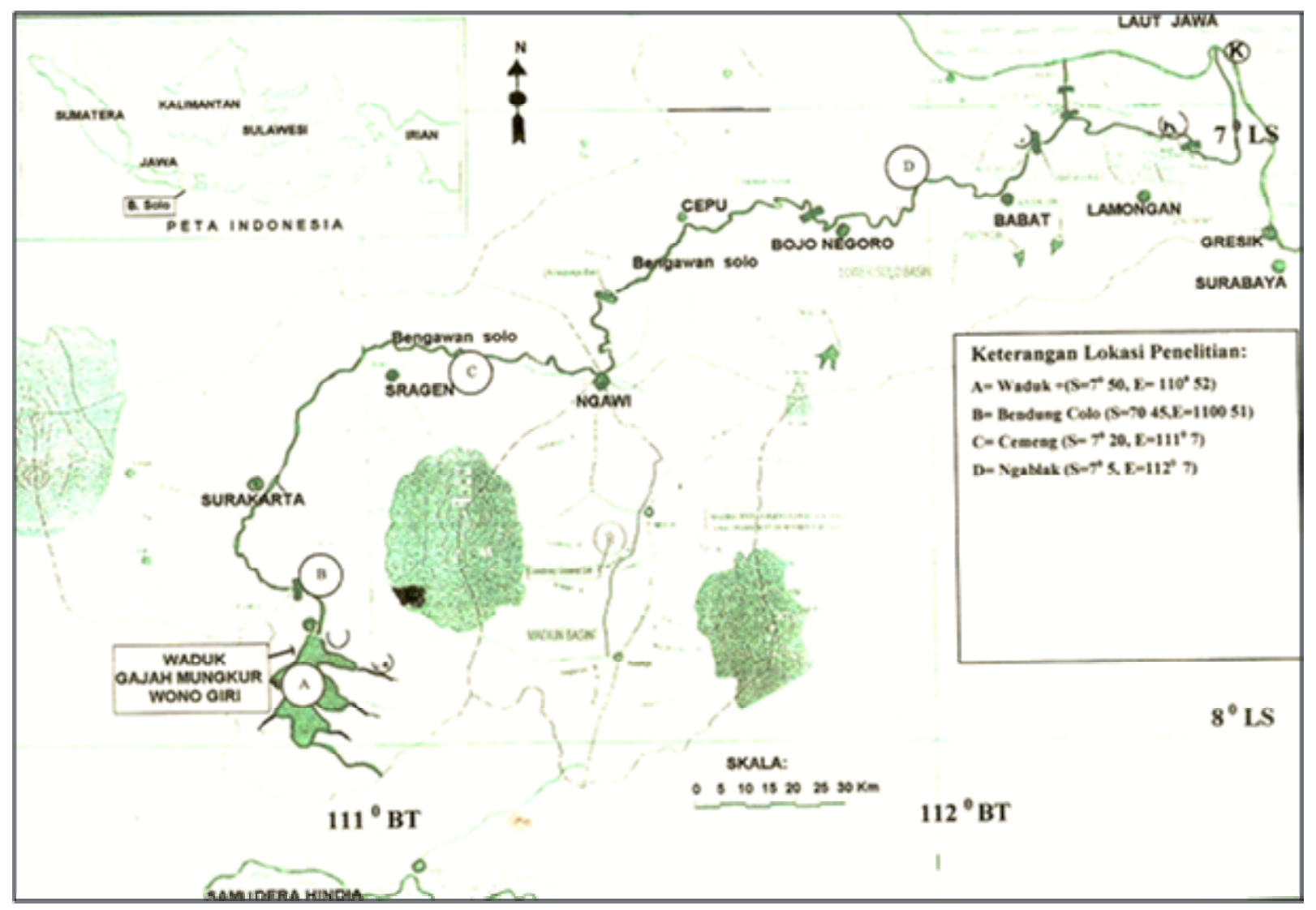

